\title{
ICHTHYOSPORIDIUM HOFERI (PLEHN \& MULSOW, I9II), AN INTERNAL FUNGOID PARASITE OF THE MACKEREL
}

\author{
By Nora G. Sproston
}

Keddey Fletcher-Warr Student, University of London

(Text-figs. I-44)

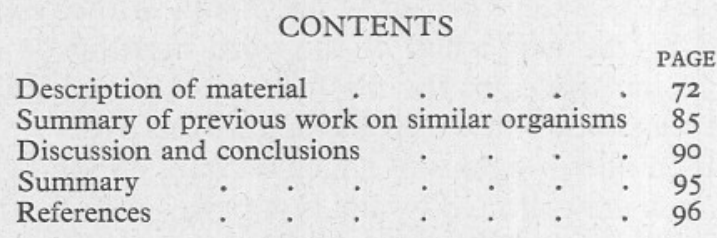

DESCRIPTION OF MATERIAL

During his routine investigations on mackerel at Plymouth on I9 March I940, $\mathrm{Mr}$ G. A. Steven drew my attention to a fish, which though externally quite normal, showed the viscera (except for the ripe ovary) to be in an advanced state of decomposition, and covered with a thick brown fluid in which were suspended numbers of yellowish granules, up to $2 \mathrm{~mm}$. in diameter. Further examination showed that the brown fluid was the result of the complete necrosis of the spleen and the partial necrosis of the kidney. The blood vessels of these organs remained as dark cobweb-like strands, toughened by the hyphae and nodules of the parasite within them; dark hair-like hyphae also spread throughout the brown fluid. All the stages, so far found, of the parasite occurred in this fish. It was evident that had the fish not been caught this infection would soon have proved fatal.

The large batches of mackerel arriving at the laboratory at frequent intervals for the fishery investigations were partly utilized in the subsequent study of the organism. Supplies became less regular in I94I and I942, but sufficient numbers were examined to show that the disease is a very serious one, showing no signs of abatement. There was a certain patchiness in incidence of infection; for instance, while one sample in I94I was completely free from it, those taken from the same locality a few days previously and afterwards showed, respectively, a moderate and $100 \%$ infection. The aggregate figures for the infection rates in I940, I94I and I942 were 70, 38 and $69 \%$; in 1943 two separate lots of four fish were received from Hull in the spring, and every fish was heavily infected. There is never any external lesion or colour change, but medium to heavy grades of infection can often be detected by the soft feel of the venter during handling. 
In its most characteristic form the parasite shows radiating hyphae, usually with a single dichotomy, growing from one of three types of central body. The length and thickness of the hyphae depend on the density of the infected tissue, and also on the degree of resistance put up by the tissues to histolytic action of the advancing hyphal tips. In low-grade infections there is little or no necrosis, and growth is more or less restricted within the 'granules' or 'cysts', which represent various forms of growth surrounded by a connective tissue sheath of host origin. These are usually stained yellowish or brown, with adherent flecks of black pigment if they occur in the spleen. In the autumn, when fish break shoal and come inshore to feed on small clupeoid fishes, the cysts come to have a silvery coating, which disappears again in the winter when the diet is no longer chiefly of these fishes. ${ }^{1}$ In compact tissues, such as the heart, or between the closely packed pyloric caeca (where cysts are often abundant), instead of the cyst being stretched radially by the growth of the parasite within, it grows in columnar form, to accommodate the hyphae advancing in the direction of least pressure. In advanced stages of infection these long galleries are common, and they contain several stages of the parasite. When resistance is low the walls are broken down at several points by the out-growing hyphae; but when it is high they effectively seal off the parasites, which eventually perish, leaving behind only fat-globules and dark acicular crystals. The persistent gallery becomes horny and dark, or silvery, according to the season (see lower part of Fig. 44). Cysts of all sizes up to about $2 \mathrm{~mm}$. can be found scattered all over the viscera, but they can nearly always be found in the kidney, particularly the head kidney; they are very rare in the body muscles and have not been found associated with the central nervous system or gonads. They occur on both sides of the intestinal and stomach walls and are frequent in the lumen.

It is convenient to start the description of the parasite from what may be called chlamydospores; these are rarely found in situ on the end of one of the radial hyphae as they become detached very readily from the spherical bunch

1 This deposition of a silvery coating on parasitic cysts in fishes, when they have been feeding on other fish, is extremely common, if not universal in teleosts, though little attention seems to have been paid to it. It is assumed that it is a redeposition of crystalline guanin from the iridocytes of the skin of the food-fish, which, like some bile-pigments, is broken down with difficulty and is laid down in the body as such. Though teleosts possess the enzymes necessary for its metabolism, the subsequent excretion as urea, this process is not very efficient, as the evidence of these temporary internal deposits appears to suggest. A certain amount of guanin is, of course, always retained in the skin of mackerel and many other teleosts in the iridocytes, which provide the reflecting surfaces responsible for the silvery venter and flanks. The correlation just mentioned was first noted some years ago and is particularly striking in the John Dory; in the summer months this fish feeds actively on small fishes, and at these times the gut is packed with scintillating silvery acicular crystals which make the search for parasites exceedingly difficult. At the same time the peritoneal cysts (of tetrarhynchid cestodes, which are always present) are also silver; but as the season advances and fish disappear from the diet, the intestinal contents are bright brown and the peritoneal cysts are yellow or brownish. Several other instances could be cited which provide suggestions for a biochemical investigation of the problem. 
in the necrotic fluid in which they occur (Fig. I). Up to ten have been found in one of these bunches, but it is not possible to state the normal number produced at a time. Their shape and size are variable, but they are usually ovoid to tetragonal and from 70 to $140 \mu$ long. The wide end bears a conical cap of a very hard hyaline substance, and this is continued as a thinner

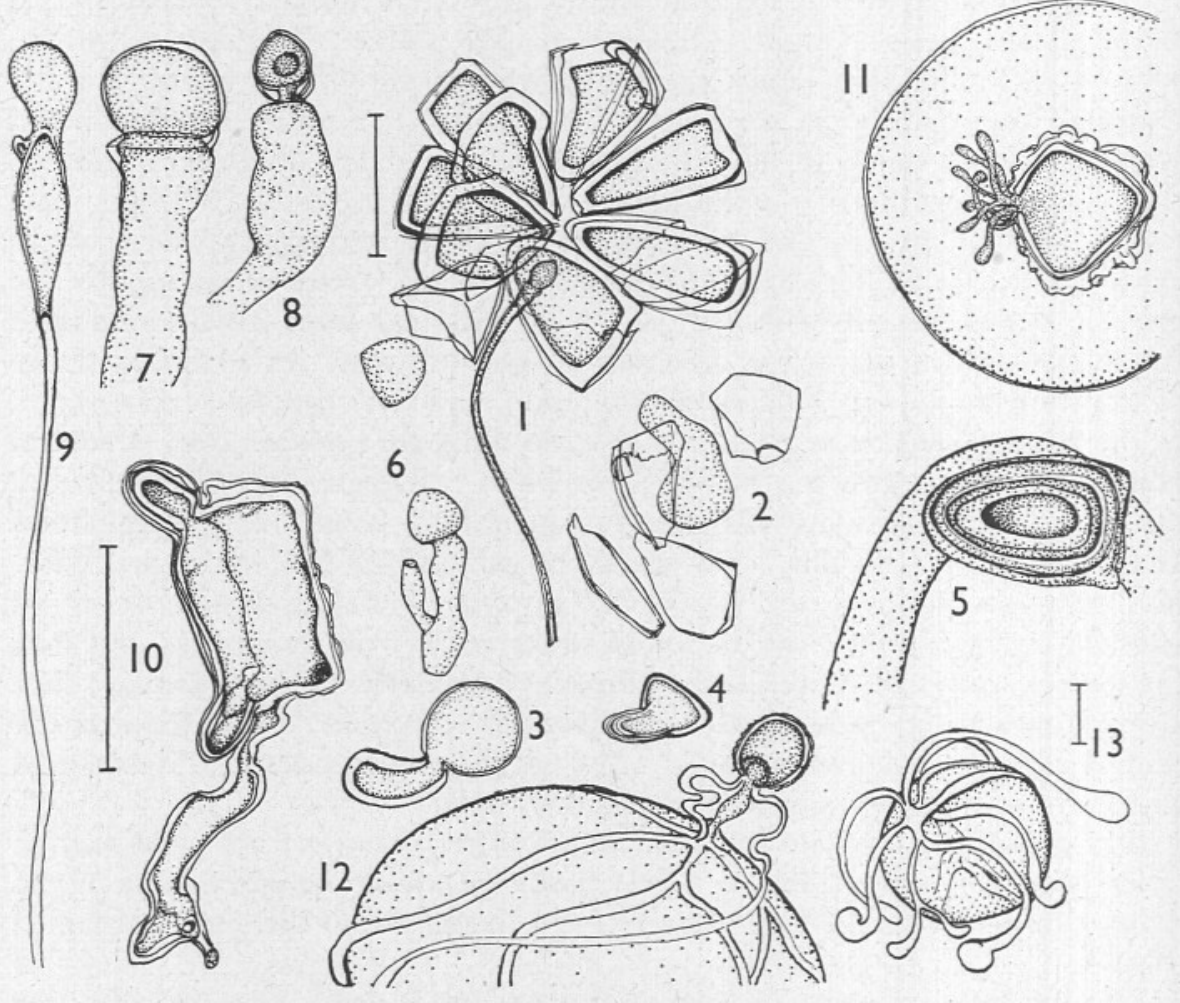

Figs. I-I3. Ichthyosporidium Hoferi (Plehn \& Mulsow). For description see text. The scale in all figures represents I00 $\mu$. The scale beside Fig. I applies also to Figs. 2 and 6, that beside Fig. Io also to Figs. 5, 7-9 and II, and that above Fig. I3 also to Fig. I2.

exospore over the whole surface, except at one small area near the widest part, which appears to be a germination pore. The exospore is insoluble in all the usual reagents; it will not stain and tests for uric acid were negative. It is so hard that when crushed between two slides the latter invariably break without damaging the hyaline cap, and the rest is only divided into three or four fragments (Fig. 2 shows a crushed chlamydospore). The endospore is very thick and hyaline, apparently of a gelatinous nature; it stains with difficulty and is negative to the cellulose tests. In shed spores it 
becomes lamellar (Fig. 5), and is usually protruded on germination (Figs. 4 and 3 ; these are drawn to a smaller scale from living material, but all other figures have their appropriate scales which have all been made equivalent to $100 \mu)$.

The hyphae produced immediately on germination are always much wider than those produced later, and in advanced growth the walls collapse behind the growing tips, so that in necrotic fluid or in blood vessels they become hair-like in comparison (cf. Figs. I9, 20). The primary 'macro-hyphae' may be very long (a portion of one from another spore is shown in Fig. 5); at other times they are short, and conidia-like hyphal bodies are abstricted very early (Fig. 6). Similar bodies, strongly reminiscent of the conidia in Empusa spp., are often found on the ends of long macro-hyphae (Figs. 7, 8). These macro-hyphae were particularly resistant to stains so that it was not possible to determine their nuclear state. Occasionally there is a hint of septa being produced before the abstriction of a conidium; Fig. 9 shows a long, collapsed, sister hypha to one producing chlamydospores, and in this the protoplasm in the outgrowing knob is separated from that behind by a convex wall of considerable thickness. This may either be the beginning of a conidium (as in Fig. 8) or, more probably, is the early stage of a bunch of chlamydospores which arise from a similar knob-like outgrowth at the end of an empty hypha (cf. Fig. I). Atypical germination, where the pore is not utilized, is shown in Fig. Io (drawn to the same scale as Fig. 5). Isolated chlamydospores are very common in advanced infections, and their presence in or near blood vessels suggests that they are dispersed by the blood or lymph streams throughout the body, coming to rest in the smaller vessels; a vascular wall, however, has not been demonstrated round all those encountered in sections. Fig. II shows a chlamydospore with the outer lamellae of the endospore much wrinkled, and though not shown the latter are darkly stained, probably with altered blood pigments from the necrotic kidney in which it was found; it has been enclosed by a thin connective tissue sheath forming the cyst wall and is suspended in a structureless semi-fluid. Germination is from one point in this example; but cysts in denser tissues, where pressure is probably greater, usually germinate in a radial manner, though it may be at right angles to the direction of pressure as in Fig. I6.

Fig. I5 shows two cysts from a resistant spleen; the smaller one is a hyphal body completely enclosed in a thick mass of connective tissue, and the larger one is a chlamydospore in transverse section, enclosed in a connective tissue sheath which completely fills the capillary in which it lies. The dark cells in the lumen at the top of the figure are mononuclears which are associated with fibroblasts in the formation of the capsule; wandering cells of this kind are shown on the inner side of the capsule in the upper cyst in Fig. I7. A chlamydospore just beginning to germinate is shown in longitudinal section in Fig. I4; the endospore has ruptured and the protoplasmic contents show unexplained segregations. No nuclei could be seen in the contents though 
there were dark-staining chromatin-like masses of various sizes all round the periphery. At an earlier stage (Fig. I5) the nuclei are very conspicuous and are aggregated round a central vacuole, their chromatin being granular and dispersed to fill the nuclear membrane. The normal state of the nucleus is a vesicle (nearly always about $3 \mu$ in diameter) with a darkly staining centrally placed mass of chromatin, about $0.7 \mu$ in diameter, suspended by finely granular strands which are continuous with a similar layer lining the nuclear membrane. It is this typical nuclear picture which has been taken by some previous authors as diagnostic of Ichthyosporidium spp. (see Robertson, 1908, 1909; Jepps, 1937; and pp. 92-93, footnote, below). When a spore is about to germinate, and at the tips of actively growing hyphae, the central chromatin spreads to fill the vesicle and gives the superficial appearance of a larger nucleus (as in Fig. I5); but in resting stages and in some hyphal bodies the central chromatin body apparently shrinks, for it may be less than $0.5 \mu$ in diameter on these occasions. Except for the conditions just mentioned, the nuclei are scattered throughout the protoplasm, which is also abundantly supplied with vacuoles containing fatty substances, though the latter are absent in resting stages. In spite of the very large number of sections which have been examined, fixed at different times of the day and year, no indication has ever been found of nuclear fission or fusion, so that sexual reproduction cannot be established from the present material.

The cyst containing the chlamydospore in Fig. I4 was occluding a blood vessel in the spleen, and there were many other cysts in the section but all were intact; the only abnormality in the tissue is the formation of a blood clot on the right of the cyst. Fig. I6 is from a section of a kidney, more than half of which was replaced by cysts in various stages of development, but all as yet intact; the remaining tissue is perfectly normal as is seen from the glomerulus, two renal tubules and a capillary with red cells which are included in the figure-the scale lies in a larger vessel which contained leucocytes and fibroblasts near the wall. This section passes above the spore but includes a portion of the outgrowing protoplasm and two young hyphae which show a typical distribution of nuclei and vacuoles. Other sections of the series show the spore protoplasm passing out into these and other hyphae the proximal regions of which become empty-a condition highly characteristic of nearly all stages of this organism, which is also shared by the Phycomycetes in general. On the left of Fig. I6 is a portion of a very large hyphal body from the same section; it is still within its connective tissue capsule, and beneath this is a laminated hyaline wall secreted by the hyphal body but deeply pigment-stained on the outside. Connective tissue cells in this and other capsules are much distorted, showing that they have been stretched during the growth of the parasite within the cyst; the one in the figure contained many thousands of nuclei evenly dispersed throughout its mass, and at the periphery was a layer of deeply staining chromatin-like bodies of unknown significance. Such rounded-off hyphal bodies are exceedingly 
common in sections, but they vary very widely in size. It is usual for these to germinate in a radial manner, and this is shown in heart tissue of considerable density in Fig. I8; this section passes through a hyphal body which was enclosed in only a thin capsule and the hyphae have perforated it at

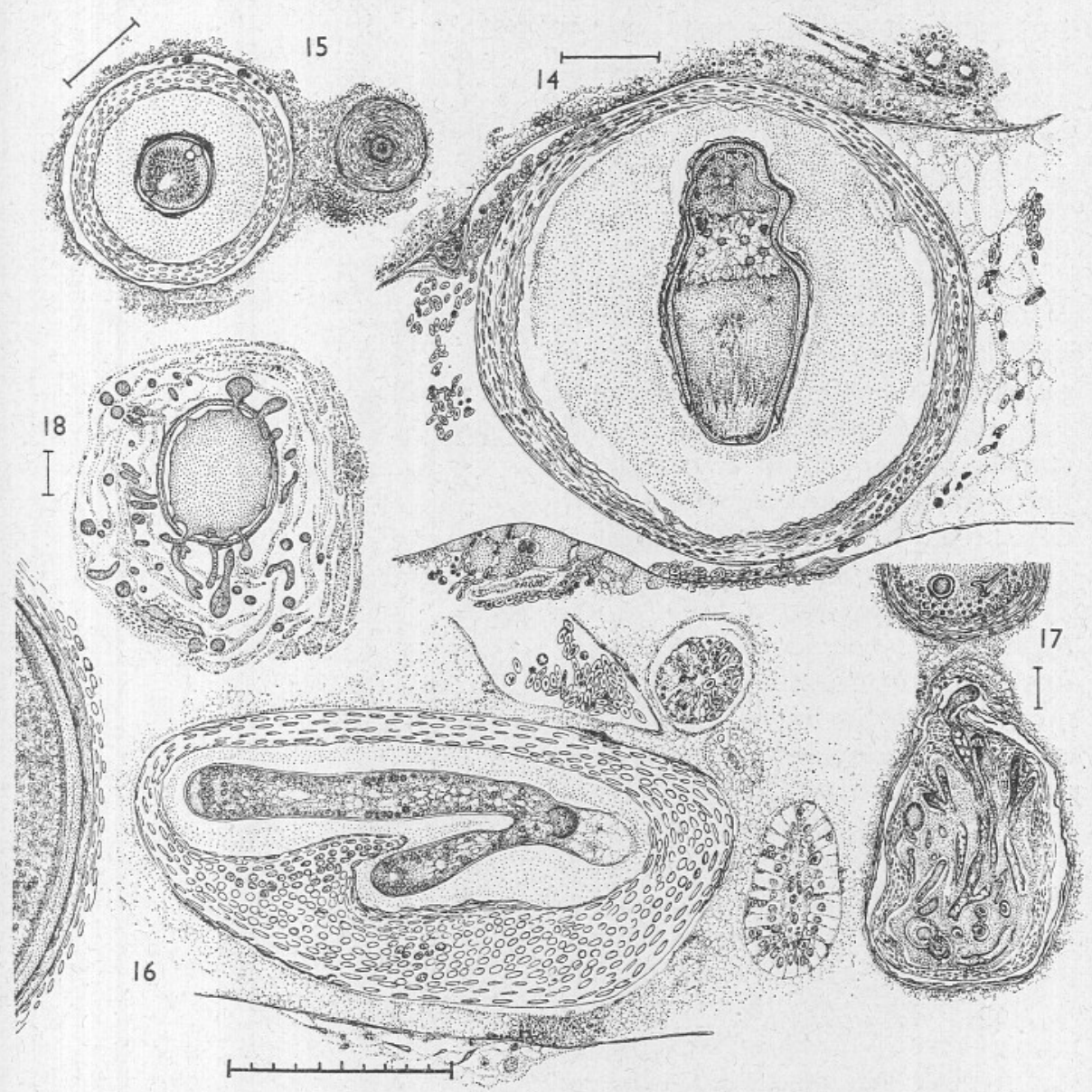

Figs. I4-I8. Ichthyosporidium Hoferi (Plehn \& Mulsow). For description see text. The scale in all figures represents $100 \mu$.

many points-they are still continuous with the central mass, the detached portions in the figure representing hyphae cut across from different levels of origin. Heart-tissue seems to be tolerant of the penetration of hyphae, for in no case was there any necrosis of the adjacent muscle fibres.

Fig. I 7 shows a section of a compound cyst, or rather gallery, in a kidney; this contains chlamydospores in various stages of germination (cf. Figs. 3, 4). 
It also illustrates a later stage of hyphal growth than that shown in Fig. I6, for an advancing hypha has succeeded in penetrating the connective-tissue capsule, and where it abuts on a kidney tubule the cells of the latter are disorganized, whereas those on the far side are still intact. Intrusive small lymphocytes can be seen massing towards one side of the lesion. The hyphal tips were all darkly stained due to granules of (?) secretory substances, probably connected with the histolysis of the capsule, etc. In the upper part of the same section is a portion of a quiescent gallery containing intrusive monocytes.

In extremely advanced infections of the kidney and spleen, the radial hyphae from a chlamydospore may measure over a centimetre in length; Fig. I9 is a perforated capsule with typical hyphae from a completely necrosed spleen, covered with brokendown pigment cells which appear as black flecks in low magnifications. The figure illustrates the collapse of the hyphal walls behind the outgrowing tips; some of the latter are preparing for abstriction as hyphal bodies, and others foreshadow hyphal fusions. In the more liquid part of the necrotic mass the hyphal tips tended to assume a more spherical shape (to the right of the figure) than in places where it was more solid (on the left of the figure); their minute structure was very similar to that in Fig. I6. In less extreme cases of necrosis the fate of the developing hyphae can be traced; thus in Fig. 20, which represents a whole

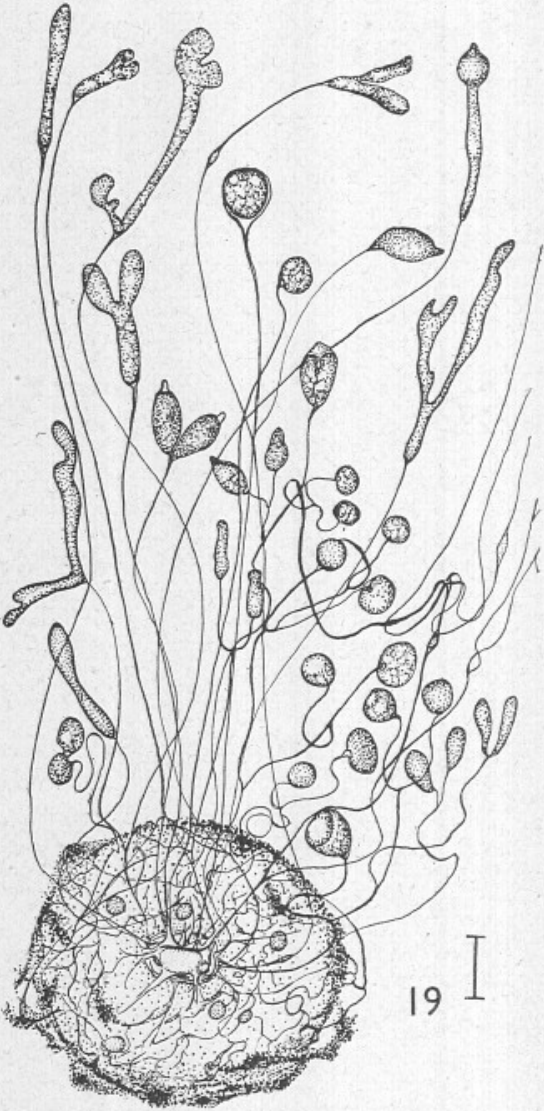

Fig. I9. Ichthyosporidium Hoferi (Plehn \& Mulsow). The scale represents $100 \mu$. mount of a moderately advanced stage in growth from a chlamydospore situated in a soft nodule from the wall of the stomach. To avoid further confusion in interpreting this complex colony, only about two-thirds of the radial hyphae have been drawn, and the loose connective-tissue capsule which extends throughout the area of the figure has been entirely omitted. The stippled ring round the central protoplast is the swollen, (?) gelatinous, endospore which has been perforated at several points by the outgrowing hyphae; their proximal portions are now collapsed and the protoplasm has grown out, some being 
abstricted as hyphal bodies which can be seen in various stages (actually lodged between the layers of connective tissue which is not depicted here). Other hyphal tips show a great variety of fusions inter se; at the top and to the right of the figure are conditions resembling the gametangia in siphonogamous species of Saprolegniaceae-the analogue of the antheridium being empty. The vesicular appearance of the central protoplast and its fringed lower edge is probably due to fixation and shrinkage, but other features shown are not artefacts, as they have all been seen in fresh material.

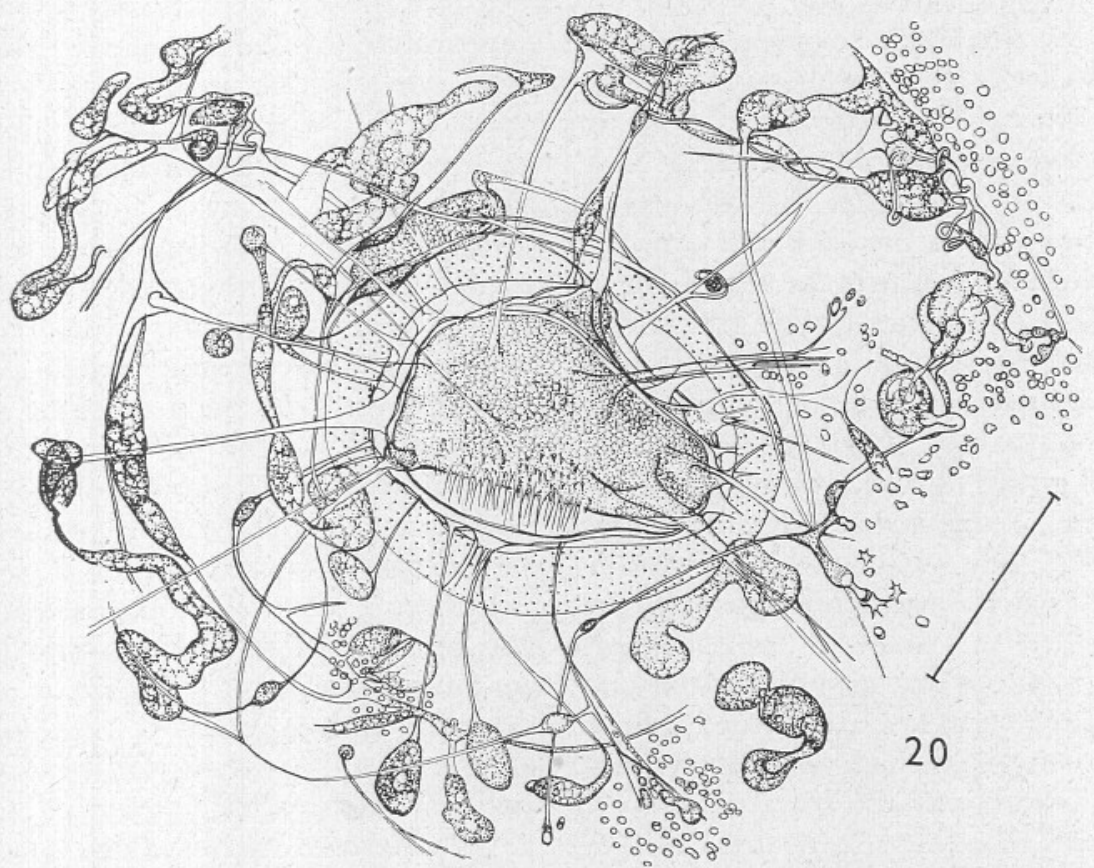

Fig. 20. Ichthyosporidium Hoferi (Plehn \& Mulsow). The scale represents Iо० $\mu$.

At various places in Fig. 20 an unusual type of reproduction is shown; the hyphal contents break up into a single series of endospores, or endo-conidia which escape by the simple rupture of the end of the hyphal wall, and show a certain degree of amoeboid movement immediately on liberation. The fate and significance of these endo-conidia is quite unknown; they were exceedingly numerous in the region of this nodule, but though they were occasionally seen in pairs, and some double the size were met with, they were never seen to fuse or display more than the slightest change in shape and position. They stain very feebly with haematoxylin and the nuclear substance is very diffuse. Though they are of the same order of size as the small lymphocytes of the fish, they contrast markedly in general appearance-the latter having a very definitely staining large nucleus and a clear cytoplasm. 
Other preparations show other types of conidia, and it is perhaps significant that all those so far found have been within, or near, rather large blood vessels, or at the side of decomposing ones. This distribution is analogous to the behaviour of certain parasitic Oomycetes such as the marine form described by Atkins (1929) in the pea-crab Pinnotheres. This fungus carries its sporangiophores outside the host so that the spores become dispersed in the currents of the mantle cavity of the Mytilus which the crab inhabits. Similarly, the sporangiophores of nearly all the Entomophthoraceae emerge from the body of the host insect, and the spores are freed into the air currents; in the body of the mackerel, however, which is a comparatively extensive micro-habitat for the fungus, the dispersal of spores from one tissue to another is effected by the sporangiophores growing into blood vessels where the blood stream acts as the dispersal agent. Fig. $2 \mathrm{I}$ is from a specimen taken from a mesenteric vein very soon after the fish was opened. The hypha acting as a sporangiophore is from the advanced growth of a stellate hyphal body; the protoplasm has grown towards the tip of the collapsed hypha, become rounded off and produced thinner walled branching conidiophores, each with a swollen end. After the original living material was drawn, it was placed, in its watch-glass of diluted sea-water, in a refrigerator and left overnight; next morning the specimen was drawn again (Fig. 22). The protoplasm in the sporangiophores had grown into the swollen ends and become divided into a number of spores, some of which had been discharged as minute amoeboid bodies while in others they remained packed within the 'sporangia'. Further search in fresh material yielded similar growths in veins, differing from each other slightly, both in the shape of the 'sporangia' and in the pattern of branching (cf. Fig. 23; the fine stippling in this and other figures represents the more or less disorganized vascular tissue). The greatest difference, however, is in the size of the spores which were always much larger in the material in situ; the latter is undoubtedly the truer picture, the small size of the refrigerator-produced spores being most probably due to the hypertonicity of the sea-water, owing to interim evaporation, causing shrinkage. There is no reason to suppose that these spores are different from the endoconidia shown in Fig. 20, notwithstanding their different mode of origin.

Clavate sporangia are not infrequent; Fig. 24 shows an example in an early stage where the nuclear vesicles appear to have swollen and the protoplasm. become segregated round them (deep focusing showed a central vacuole in the sporangium). Fig. 25 is at a still earlier stage, but that shown in Fig. 26 was unusual: the contained 'spores' appeared to be slightly concave and discoid; they were highly refringent, and may have been undergoing a form of fatty degeneration, as it is otherwise unknown to find fat droplets in reproductive bodies in this mackerel parasite.

A more usual development of the hyphal tips is not the direct production of sporangia, but the participation in some form of hyphal fusion; this may take place between unequal branches of a single dichotomy, or between the 


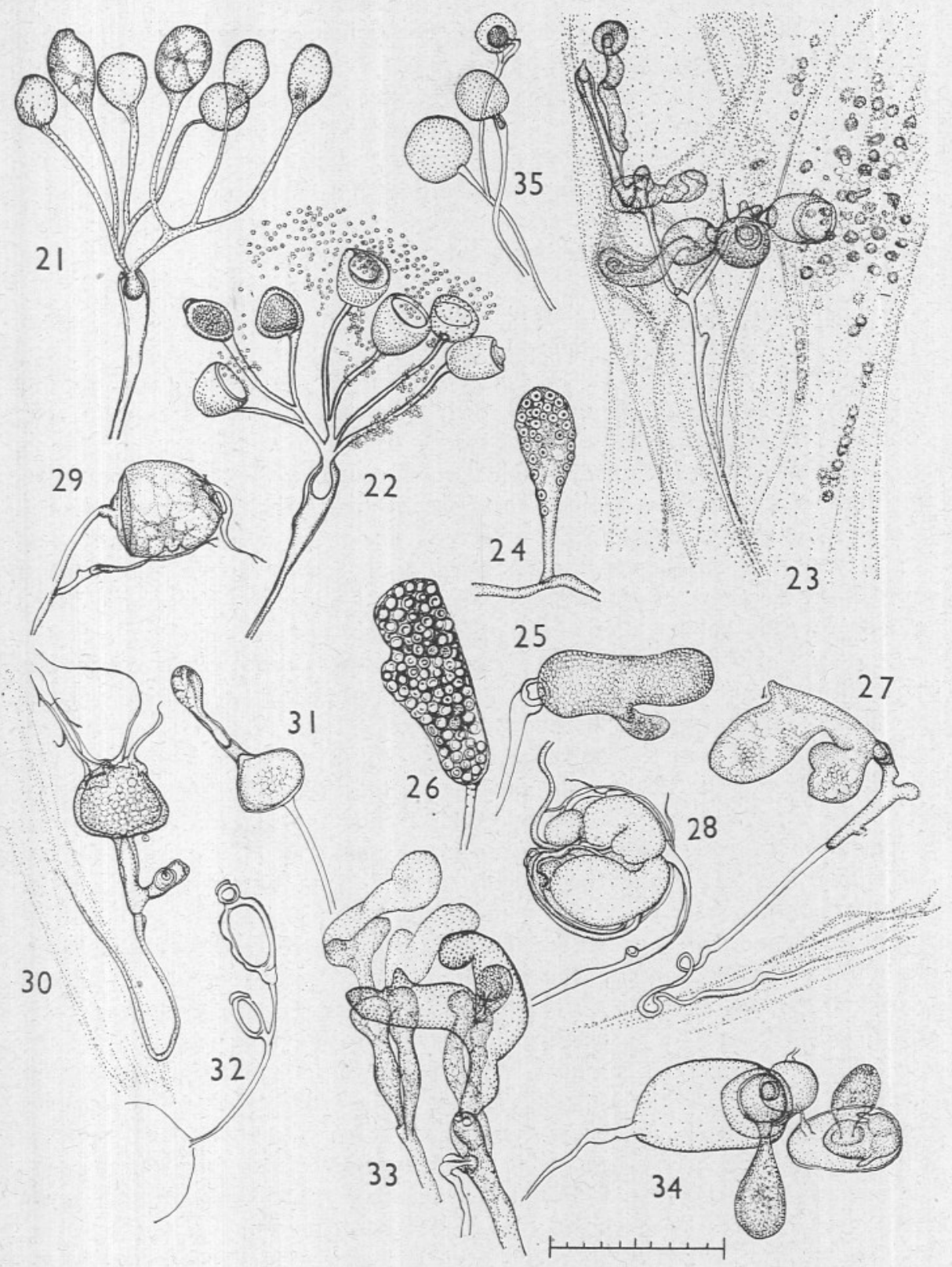

Figs. 21-35. Ichthyosporidium Hoferi (Plehn \& Mulsow). For description see text. The scale represents $100 \mu$ and applies to all the figures. 
ends of sister hyphae (precursors of such fusions are seen in Figs. I9, 20 and 27). Such a fusion may be followed by further outgrowths and renewed fusions (Figs. 33, 34). On the other hand, the fusion may be unilateral, and the hypha receiving the protoplasm may become transformed into a sporangium-like body as in Figs. 20, 29, 30 and 35. In the material shown in Fig. 29 the entry of the protoplasm from the subsidiary hyphae was seen, though no association of nuclei could be detected. It is to be noted that in none of the forms was there any structure resembling a columella, which superficial resemblance to the Mucorales might suggest (cf. Figs. 21, 22, 23 and 29).

Hyphal bodies abstricted, simply, from the ends of hyphae (as in Figs. 6, $7,8,19,20,31,33,34,35$ and 39 ), either proceed at once to round off and grow hyphae (as in Fig. 4I) or become spherical and consolidate, loosing the fatty vacuoles and secreting a wall from which the protoplasm later contracts. These spores from hyphal bodies are very common and of variable size; they may become centres of radial germination in the tissues at any size, but there is apparently a resting period during which the nuclei multiply and considerable growth in girth takes place (cf. the sector of a large example in Fig. I6). Quite frequently the encysted hyphal body divides and one or more of the enclosed spherules may divide again, a new cyst wall being secreted at each division so that compound spherules are formed containing one or more orders of smaller spherules. The sizes of these encysted hyphal bodies range from about $50 \mu$ to over a millimetre in diameter-the larger spheres are usually in the region of $250-570 \mu$ across. It is evident that they are moved about the host by the blood stream, and in this they agree with the hyphal bodies of the Entomophthoraceae, in the bodies of insects, as shown by Speare (I922), Sawyer (I933) and others. The germination of the hyphal bodies in insects is very similar to those in the mackerel; Speare (1922, fig. I3) has shown that it is sometimes radial, though the resulting hyphae are not usually dichotomously branched in the examples from insects.

There is some reason to believe that spores produced from hyphal fusions, about to be described, are the chief means of dispersal of the fungus throughout its macro-habitat, as distinct from the foregoing types of reproductive body which are sufficient for dispersal in the micro-habitat (viz. the body of the fish). Fig. 27 illustrates a phase of hyphal development which appears to precede fusion; but just as frequently it takes place between the tips of neighbouring hyphae, which coil round each other prior to actual fusion, in a manner not easy to illustrate. Fig. 28 shows an example of this intimate coiling of branches of the same hypha; the smaller one having broken away in the process, leaving a scar on the now empty 'sporangiophore'; and this also shows the shrivelled remains of other neighbouring hyphae which invariably participate in this type of fusion (both Figs. 27 and 28 were taken from the same blood-vessel colony in a necrosed spleen). Later stages of these 'spores from hyphal fusion' are seen in Figs. $3^{6-38}$. In course of time 
the contents consolidate and recede from the hardening wall, which is always wrinkled, the 'wrinkles' representing the remains of the ancillary hyphae which contributed to the later stages of the hyphal fusion. This outer wall usually becomes stained brownish from the necrotic mass in which it comes to lie; in addition there is almost always a $\mathrm{Y}$-shaped area visible just below the outer wrinkled wall (Figs. 13, 37 and 44). This is the site of the primary fusion of the parent hyphae, their lumen often retaining an axial thread of dark (?) protoplasm or other residual matter. Fig. 36 was taken from an old stock 'culture' and the outer 'spore' wall has been partly dissected away to show the disposition of the parent hyphae and two large consolidated masses

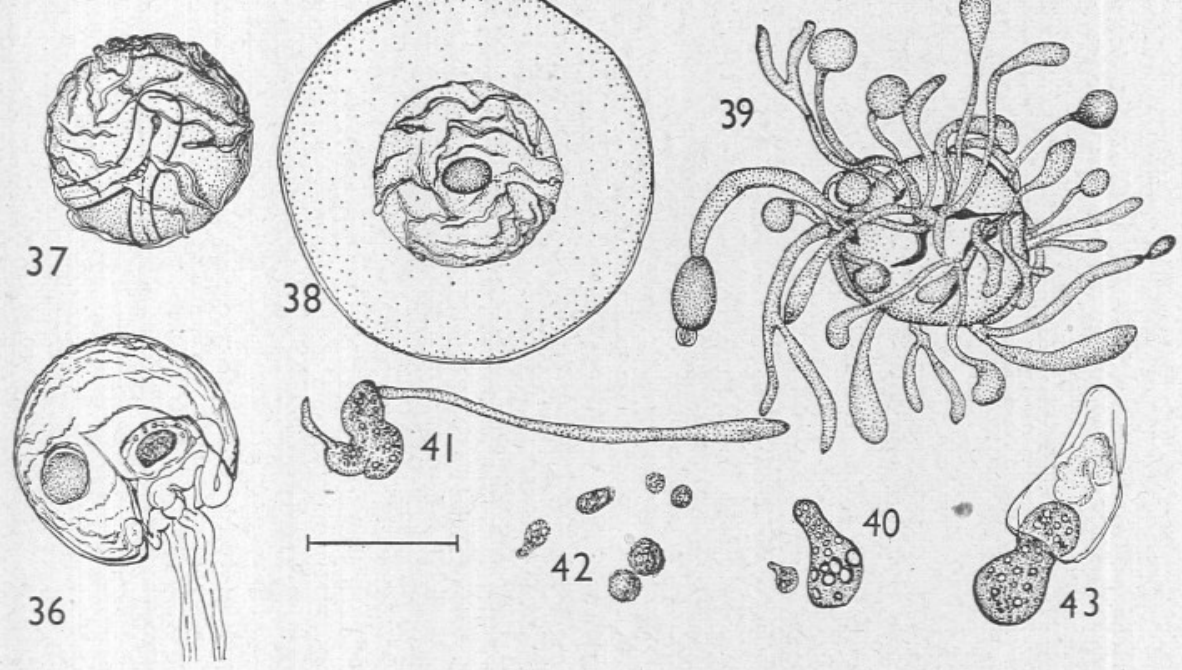

Figs. 36-43. Ichthyosporidium Hoferi (Plehn \& Mulsow). For description see text. The scale represents $100 \mu$ and applies to all the figures.

each with a separate wall, which were found within. If nuclear fusion had been seen this body would be analogous to a zygospore, but such names are unwarranted in the present instance. Sometimes these 'spores from hyphal fusions' are found in the gut contents in the bare state (Fig. 37), or are enclosed with a structureless granular fluid in a thin capsule of host origin (Fig. 38). In both states they have been kept for over three months, mostly in the refrigerator, and have afterwards germinated (Fig. 39).

Germination can be induced, sometimes very rapidly, and sometimes taking several hours, by removing refrigerator material to tap water or dilute saline at room temperature. It very frequently takes place from a single point and the rather wide hyphae tend to envelop the old 'spore' or 'cyst' (Fig. I3), or an adjacent one (Fig. I2, taken directly from necrosed viscera); or it may be more luxuriant and the hyphae emerge from several points of rupture of 
the cyst (Fig. 39). Though the latter figure was taken from an old stock 'culture', it differs in no respect, except the darker colour of the hyphae, from abundant examples in freshly caught fish; at least two hyphal bodies or 'conidia' can be seen becoming abstricted.

Hanging-drop and other cultures in various media were all unsuccessful owing to the overgrowth of contaminants from the original material. Various experiments involving the sterilization of different types of resting 'spores'

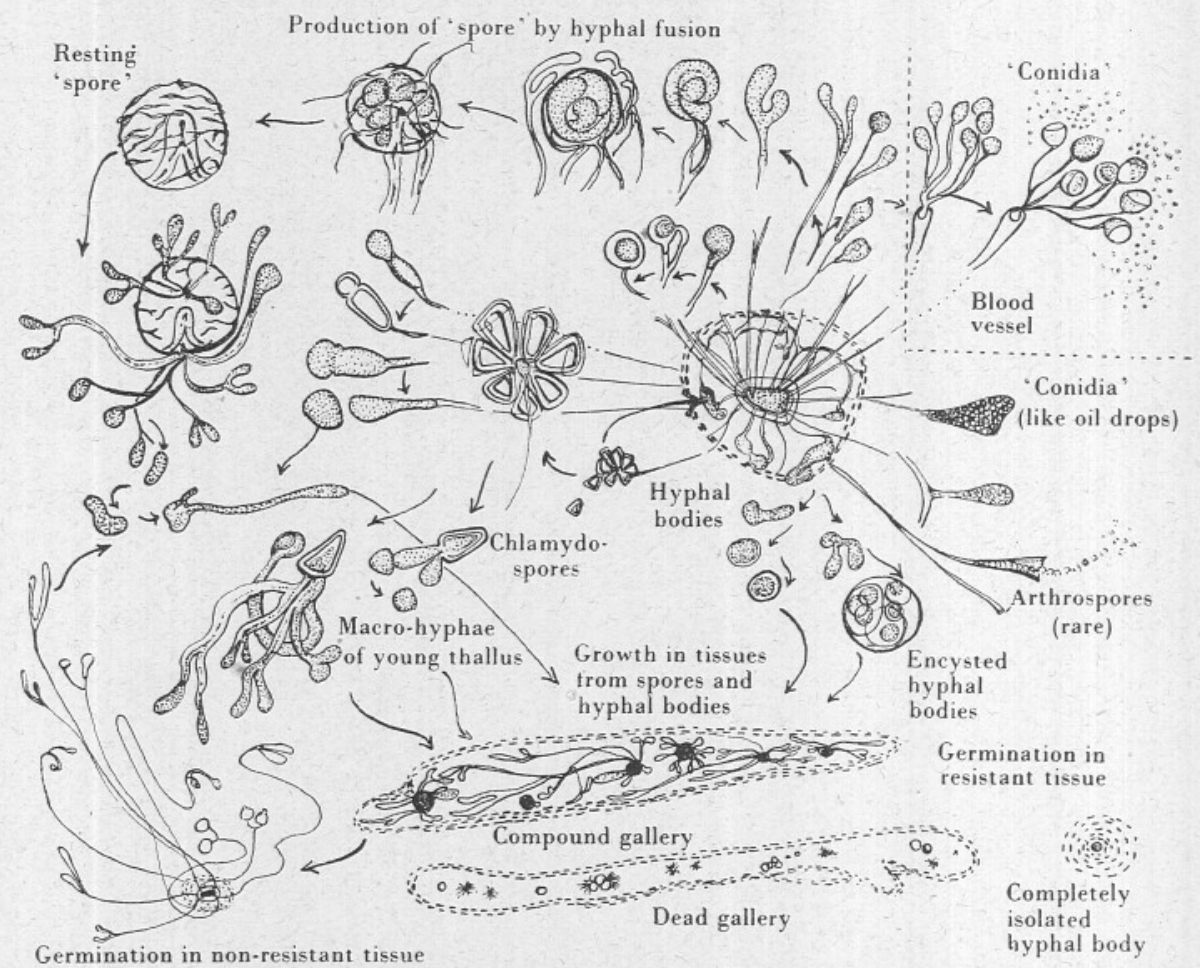

Fig. 44. Diagram of the sequence of growth forms in the life cycle of Ichthyosporidium Hoferi in mackerel. The broken lines represent connective tissue of the host (see text).

were also disappointing. The best results were obtained by making thin covered smears directly from the necrotic mass from a badly infected fish; in this way stellate germination has been seen at various stages in several of these 'spores from hyphal fusions', and other stages have been followed in the subsequent rounding off and germination of abstricted hyphal bodies (Figs. 40, 4I). Fig. 42 represents endoconidia at various stages of growth in the stock culture fluid, though their ultimate fate could not be ascertained.

An attempt has been made to summarize the forms of growth of this fungus in the mackerel, and some of their probable relationships inter se 
(Fig. 44); but at present I do not consider I shall be justified in selecting a series of forms for a 'normal life cycle'. Improved culture methods, when fresh fish become obtainable, will probably throw more light on the significance of the various forms described here.

\section{Summary of Preyious Work on Similar Organisms}

There are several records in the literature of organisms very similar to some of the growth stages met with in the mackerel, both from freshwater and marine fishes; but this is the first time such a wealth of forms has been described from a single host species, and some of the forms are new. There is much to be learnt about the influence of other hosts on the growth of this parasite, and until it can be proved that other records from continental and American fishes represent distinct species, all these forms will be regarded, provisionally, as conspecific.

Caullery \& Mesnil (1905) created the genus Ichthyosporidium, with I. gasterophilum as the type species, for organisms from the viscera of Motella mustela and Liparis vulgaris, from Wimereux. Their figures and descriptions refer to structures very similar to detached hyphal bodies in mackerel. Their fig. I06 shows a short bifid structure with rounded ends, similar to some shown in Fig. I9 herein, but without the long empty hypha; in other figures they show simple ovoid or globose bodies without a thickened wall. Plasmotomy was found to take place and bi- and uninucleate forms were common; no motile stages were discovered, but nuclear division was found to occur and was simultaneous for all nuclei in the syncytium. With these data it is not surprising that the authors classified it as a Haplosporidian (fam. Bertramiidae); they described a very similar 'species', I. phymogenes, from Crenilabrus melops from the same place.

Robertson (1908, 1909) found similar rounded and lobed forms, sometimes showing plasmotomy, also a simplified simultaneous mitotic division, and 'trophic' forms within a thick cyst, the outer layers of host origin, and the inner closely adherent to the syncytium of the parasite. All these bodies occurred in the tissues of various visceral organs of a flounder from Millport, Scotland (collected 1906), and in a sea trout from Ross-shire; she also notes that similar forms were found by her in a haddock from Aberdeen. It is now evident that her descriptions referred to stages in the growth of hyphal bodies; but in the light of Caullery \& Mesnil's work she identified her organisms with the genus Ichthyosporidium, without naming the species. Recently, however, on examination of the present material from the mackerel, she has indicated her agreement that the two forms are in all probability identical, and have fungoid rather than protozoan affinities (personal communication).

Johnstone (1906) found that plaice from the hatchery tanks and ponds at Port Erin showed heavy infections of the liver and kidney with a fungoid organism which he considered to be near to the genus Conidiobolus (Entomophthoraceae), his identification being based on the presence of 'mycelium 
and conidiophores' and of double-walled 'resting spores'. The figures which he gives agree with mine from the mackerel (Figs. 2I, 23 and 43-though as he found 'resting spores' only isolated in sections it is not possible to tell if he had chlamydospores or thick-walled resting hyphal bodies, but they were probably the former). He was led to make his identification partly by the large numbers of dead and dying beetles and other insects in the ponds, which were assumed, without evidence, to be the vectors of the parasite. Superficial lesions were present on nearly all the plaice and were thought to provide routes of entry for the fungus. In later investigations at the same place, Riddell \& Alexander (I9I I) showed that the bacterial disease responsible for the skin lesions precedes the occurrence of the fungus, though they added nothing to our knowledge of the latter.

Laveran \& Pettit (I9I0) found what are apparently hyphal bodies in the trout, and identified the organism with that (partly described, but not named) from the same fish by Hofer (1893, I904 and 1906) and others, implicated as the cause of 'Taumelkrankheiten' when cysts occur in the central nervous system and affect the co-ordination of movement in the fish. They accepted it provisionally as the haplosporidian of Caullery \& Mesnil, but noted that there were indications of its having plant affinities. Plehn \& Mulsow (I9II) again found the parasite in salmonids, and as in Laveran \& Pettit's material it was attacking the viscera, and they were the first to grow it in cultures. Their tissue sections containing the parasite agree very well with mine of the primary germination of chlamydospores and walled hyphal bodies from the mackerel; they also found encysted spherules [hyphal bodies], and they used these as the inoculum. In bouillon they obtained a profuse growth of hyphae, which to judge from their fig. 4 is more profuse and branched than any so far recorded from a fish; on solid media the spherules germinated from a single fissure producing bunched hyphae with clubbed and globose ends, very much like that shown in Fig. 39 herein. Some of the latter germinating spherules figured by Plehn \& Mulsow correspond, apparently, with the 'spores from hyphal fusion' from the mackerel, since they show long wavy wrinkles over their surface suggesting the withered ancillary hyphae described here. From the results of culture they concluded that it was a fungus belonging to the Phycomycetes, and near to the Chytrids; they reported neither hyphal fusions nor sexual reproduction. In transferring this and allied organisms to the Fungi, they created a new genus, Ichthyophonus, and named the forms occurring in salmonids $I$. Hoferi.

Pettit (I9I3) re-examined the organism from several trout in aquaria and reported cysts [hyphal bodies] up to $200 \mu$ in diameter with a double capsule; he found a simplified mitosis, though the nuclei are stated to be only $2 \mu$ across. $\mathrm{He}$ also found 'spherules' $15 \mu$ in diameter with fat droplets and a large nucleus, free in the intestinal contents, some time before the disease showed itself in the organs. He suggested that the infection may have come from small gadoids used as food (these were infected with Lentospora (Myxo- 
sporidia)); no stage was found in the aquarium or in the water supply to the fish farm. Warming of the water was suggested as a prophylactic, to avoid undue lowering of the resistance of the trout in cold weather when the disease became a menace. The spleen showed infiltration of 'altered haemoglobin' and necrosis (p. IOOI), and other pathological changes are described. He accepts the identity of Hofer's, Robertson's, Laveran \& Pettit's and Plehn \& Mulsow's organisms with the one he describes, but corrects the nomenclature to Ichthyosporidium Hoferi (Plehn \& Mulsow), since the new generic name was not justified.

Neresheimer \& Clodi (I9I4) were able to describe a complete life cycle of this organism causing 'Taumelkrankheit' in salmonids, and to show how amoeboid spores, from the clavate hyphal tips, can be liberated into the tissues; they also describe hyphal bodies in the tissues with a similar reactiontissue capsule to that found in mackerel, but the other forms of 'sporangia' and chlamydospores were not found by them; moreover the hyphae in the tissues were always short and wide. They were successful, however, in showing that few-nucleate forms penetrate the gut wall and that infection is direct from fish to fish without the intervention of an intermediate host. They follow the nomenclature of Plehn \& Mulsow and consider the parasite to be a fungus.

Léger \& Hesse (I923) found a similar infection confined to the intestine of wild trout in the Alps; but here again the tissue forms appear to have been simple rounded hyphal bodies of various sizes, the nuclei increasing in number by a simplified mitosis, the spherical syncytium ultimately dividing into eight secondary masses, each of which, when dispersed by the rupture of the thin cyst, was capable of repeating the cycle. Nothing of this kind has been found in the mackerel; the readily observed mitosis and the production of equal sized bodies of a fixed number has not been described in forms of this parasite in marine fishes; moreover, they describe uninuclear masses found by others in the trout intestine. The simplicity of the forms occurring in the trout may be realized since these authors remark on the close similarity to the other grave disease of salmonids-Calkins' (1900) Lymphosporidium truttae, an undoubted protozoon. They name their form Ichthyophonus intestinalis, on account of its restriction to the intestinal wall and lumen. In 1924 Léger described a new species, Ichthyophonus lotae from the intestine of the freshwater Lota. Later Léger (1927, I929a, b) reports the results of culturing the organism from trout and other cases of the disease from these fish and he shows that it has all the characters of Basidiobolus in culture; the hyphae are divided into cells with a single, comparatively large, nucleus and there is typical zygospore formation. In spite of his figures being quite unlike any of the forms hitherto described as congeneric with Ichthyophonus Hoferi, he groups all the forms found by him in the alimentary canal of trout into the species $I$. intestinalis, and maintains that they are congeneric with $I$. Hoferi. He states that he would be justified in including them in Basidiobolus; but his intentions are not clear, for he also uses the following 
combinations without comment: 'Ichthyophonus (Basidiobolus) intestinalis' (I929a, p. 82, in legend to fig. 4) and 'Basidiobolus (Ichthyophonus) intestinalis Léger \& Hesse' (1929a, p. 83). His accounts, however, do not furnish conclusive evidence that the undoubted Basidiobolus sp. (Entomophthoraceae) of the cultures is the same as the organism producing the disease in trout; if this is true, then it must be named B. intestinalis (Léger \& Hesse, 1923) Léger, I929, and not regarded as congeneric with Ichthyophonus Hoferi.

A form with very short wide hyphae and thick-walled 'spores' (occurring only scattered in the tissues), has been described in the herring from North American Atlantic waters by Cox (1916, a brief description without classification), Daniel (1933a,b), and in more detail, by Fish (1934); the latter author finds Pomobolus pseudoharengus to be an occasional host when it frequents the same waters as infected herring. He also confirms the findings of the same parasite in Pseudopleuronectes americanus by Ellis (I930a,b), which Fish shows becomes infected by eating diseased herring. Cross-infection by cysts [? hyphal bodies] from herring to the flounder was established experimentally. All these American forms are clearly conspecific, but they differ consistently from the forms from the eastern hemisphere in the regular occurrence of a linear plasmotomy in the short hyphae, forming a row of few-nucleate rounded bodies issuing from a cornucopia-like expansion at the end of the ruptured hypha. The nearest parallel to this found in the mackerel is the rare condition of the 'endo-conidia' formation, by the fragmentation of hyphal contents producing minute (? uni-nucleate) bodies (see Fig. 20 herein); but the relatively large rounded bodies figured by Daniel (1933 $a$, figs. 6, 7, 8, 9 and I5) and by Fish (I934, pl. I, figs. I, 5) have no counterpart in the mackerel. There is thus a suggestion that the American forms belong to a distinct species, though the differences might equally well be due to the influence of a different host on the growth of the same parasite. Moreover, in the herring, the American authors point out that in advanced stages the muscles are infected, and pus-sacs develop which eventually perforate the skin; the incipient external lesions being indicated by black spots, due to the diseased skin failing to reflect light. In mackerel the body musculature has never been involved to this extent by the parasite in question, and even the skin and gills of fish in extremis show no signs of disease.

In view of its abundance during the period of investigation (1940-3), it is curious that the disease in mackerel had only been recorded from a single fish previously. This specimen was collected in July 1912 off Walney Island (Irish Sea), and the description published by Johnstone (I9I3), is equivalent to a moderately advanced infection. He described only three growth forms: large [hyphal] bodies in the kidney enclosed in capsules of connective tissue, and smaller [hyphal] bodies in the liver, which showed their own capsule in addition to that of host origin. Some of these bodies had short branched hyphal outgrowths invading the tissues; and lastly, there were some thickwalled germinating 'spores' with short wide hyphae. Small cysts, often 
compound and well encapsuled in connective-tissue, were found on the peritoneum, particularly in the region of the pyloric caeca. He considers the organism to be 'very closely allied to the species of Plehn \& Mulsow, if it is not identical' (p. 32), and says that it is 'rather different' from a 'closely similar condition' described by him in plaice and attributed (I906) to Entomophthorinae, near to Conidiobolus. The latter parasite was again found by him in Pleuronectes platessa from Port Erin in I9I6, and briefly described later (I920) without being named; it showed a fairly restricted growth of hyphae in the wall of the intestine, and partial necrosis had occurred. He also figures a rugose body with outgrowing clavate hyphae ("mycelium with sporangiumlike bodies', p. 24) from the liver. He does not deny its identity with the mackerel parasite, as he is stated to do by Fish (I934, p. 3), nor is there any evidence for so doing; proofs either of identity or of distinctness are both lacking.

In the same paper (I920, pp. 25, 27, figs. 3 and 4) Johnstone describes elongated capsules containing a degenerate homogeneous substance; they are conspicuous in the musculature of the hake by their dark colour, and he identifies them as degenerate cestode larvae, though they show no sign of calcareous corpuscles or hooklets, and no terminal enlargement, as is common with pleurocercoid cysts, even when degenerate. Such bodies have been described before, and Williamson (1913, pp. 8-9, pl. 3, figs. 56, 60, 69, 70 and 73) referred to them as the 'columnar disease' of cod, or 'the brown parasite', because of the stained outer wall; they were common between the body muscles, some being empty and others 'of a hard cheesy consistency'. $\mathrm{He}$ also described similar 'columns' in connexion with Dokus adus, the 'intra-capillary parasite' of Gadus aeglefinus, and thought to represent its final stage in the fish; they often had a very friable wall, exactly like the 'dead galleries' found in mackerel. It is most likely, therefore, that all these bodies represent the remains of a similar infection to that of the mackerel. In the latter fish, cestode cysts are always abundant, but it is quite easy to distinguish them from the simple tubular inter-muscular galleries of the fungus (both these are also frequent between the packed mass of pyloric caeca).

Williamson's description of Dokus adus (I9I3, pp. 4-7, pls. I-8) is rather confused, as hé was uncertain whether it was a plant or an animal, though he inclined to the latter, since the out-growing hyphae were described as larvae leaving the cyst; yet he detected no movement of any phase. His figures, however, show clearly enough that he was dealing with a parasite morphologically identical with the fungus of the mackerel. He calls it an intracapillary parasite and his figures of small blood vessels distended with cysts, of bile-stained masses in the necrosed viscera surrounding the spore-like bodies, which give rise to radiating hyphae with bifid clavate ends, all have exact counterparts in the present material. He describes long tubes between the muscles containing out-growing hyphae, and rugose spores ['spores from hyphal fusions'] are also figured. He does not show the thick-walled chlamydo- 
spores, the branched conidiophores, nor the various forms of hyphal fusion, nor some other growth forms found in the mackerel. He admits that it is in many respects similar to Johnstone's Conidiobolus-like fungus from plaice.

In a separate part of the same paper (I9I3, p. I2, pl. 2, figs. 39, 46 and 50), Williamson describes what appears to be the same fungus from the kidney of Brosmius brosme and of Gadus callarias-the growth of the former being especially typical. The disease in the haddock is apparently common enough to have earned the local names of 'spotted haddock', 'greasers' and 'smelly haddock'; there is no external sign of the trouble, but in gadoids, like clupeoids, the muscles become infected, and stained areas round the cysts are visible to the naked eye so that the fish have to be condemned as human food.

Quite recently, what may be the same parasite, has been found to be of economic importance by Fischthal (1944, pp. 35-6) on the north-east coast of the United States, where it occurs as cysts, parallel to the muscle fibres of Zoarces anguillaris; clusters of cysts may form a brownish concretion, or actively growing 'trophozoites' may cause a hyaline degeneration of the muscles. The fish is marketed in fillets which have to be examined against a strong light so that infected ones can be discarded. No mention is made of the viscera being attacked, nor of marked necrosis, but an aggregate infection rate of about $7 \%$ is recorded between March and August I943. The morphology is not described beyond the mention that cysts, II $-23 \mu$ in diameter contain ovoid spores $4-7 \mu$ long. The larger cysts are $3-5 \mathrm{~mm}$. long and $0.3-\mathrm{I} \cdot 2 \mathrm{~mm}$. wide. It was described as a sporozoan, and placed in the genus Ichthyosporidium.

\section{Discussion AND CONCLUSIONS}

The absence of a plasmodial stage in the life history excludes the present organism from Myxomycetes, and this and its capability of forming an organized thallus, from the Haplosporidia; for though the minute 'endoconidia' are apparently amoeboid and naked, no regular vegetative stage has been found without a wall surrounding the syncytium. In the type species Ichthyosporidium gasterophilum Caullery \& Mesnil (I905, fig. I06) the original figure is apparently from a bifid hyphal body, recently abstricted from its parent hypha (such hyphae, however, are not mentioned) as the protoplasm is seen receding from a clearly drawn wall, corresponding to the proximal region. The parasite from Motella mustela, described under this name by Alexeieff (I9I4), is evidently quite a different organism, probably much more closely related to Amoebidium (see Chatton, 1906), for the prevailing phase is a binucleate amoeba-like body without a distinct wall, and uninucleate spores are another characteristic. He places this organism in a new suborder of 'Mycetozoa-Haplomycetozoae (fam. Haplosporididae)'. Debaisieux (I9I6) in reviewing Coelomycidium, Blastulidium, Amoebidium and Alexeieff's Ichthyosporidium gasterophilum, places these genera in the family Coelosporidiidae which he considers to be near to the Chytrids. Debaisieux does 
not examine the validity of Alexeieff's $I$. gasterophilum; but it is clearly not synonymous with $I$. Hoferi as is suggested by the latter author.

The presence of an aseptate thallus, with well-developed non-cellulose walls, places the organism in Phycomycetes. The mode of development of the branched 'conidiophores' from the ends of hyphae (see Figs. 2I, 22) is reminiscent of some Chytrids, such as Urophlyctis, as Prof. Bennet-Clark has pointed out (personal communication); though unlike the majority of this group, flagellate spores are unknown. (The spores are amoeboid in Protomycetaceae, but there is no great development of hyphae in any of the members at all comparable with that in Ichthyosporidium in mackerel.) In the present accepted classification the only possible position for this genus is in Entomophthorales (Zygomycetes), in which flagellate spores are absent, and most other characters are in agreement. The types of fusion of the ends of vegetative hyphae are externally similar in Ichthyosporidium to those of several widely different members of the Phycomycetes; forms resembling the gametangia of Syncephalus nodosa (cf. Fig. 20), Pythium de Baryanum (Figs. 20, 34 and 35), and siphonogamous species of Saprolegniaceae (see Figs. 20, 29) have been found in mackerel. ${ }^{1}$ The similarity may only be superficial, since no nuclear fusions have been seen. Among the Mucorales, Mortierella is without a columella at the base of the sporangium, and there is some further agreement here, for after hyphal fusion the zygospore becomes covered with a layer of vegetative hyphae analogous to the condition in the 'spores from hyphal fusion' in mackerel (see upper figures in Fig. 44, and $\mathrm{Ou}, \mathrm{I940}$ ). Nevertheless, the participation of these ancillary hyphae may also be compared with the development of haustoria on the zygospores of the Entomophthoraceae (see figures in Thaxter, I888). Like the condition in Zygomycetes (in contradistinction to that in Oomycetes) the protoplasmic division in the clavate sporangia is probably centripetal. The dome-shaped conidia [or hyphal bodies] developed on the ends of some of the hyphae are in most respects similar to those of Empusa and its allies, except that they are apparently not shot off with such violence; in Massospora cicadina Peck,

1 Though there is no question of close relationship to the present parasite, it is to be noted that adaptation to true internal parasitism has been achieved in several genera of the Phycomycetes; Mucor sp. and Rhizopus equinus Constantin \& Lucet, I903, for instance, were demonstrated, both naturally and experimentally, in the kidney of the rabbit by Savouré (1905). Stellate germination occurred producing clubbed hyphae, at first within capsules of host tissue, and then normal growth proceeded outside the capsules. A habitat, perhaps hitherto, unrecorded, for Saprolegnia sp. was recently found while examining yearling trout which had died from acute enteritis in an aquarium in the Zoological Department, University of Cambridge. The fungus had attacked the gills and fins to a moderate extent, but in addition there was a felted mass of mycelium growing on a much disorganized mucosa throughout the whole length of the intestine, but particularly luxuriant in the rectum. The mycelium was producing abundant sporangia, but no sexual stages were found; the whole organ was very much injected but there were no localized pus-sacs.

A similar intestinal trouble has been recorded in a marine fish, Mugil chelo, at Banyuls, caused by an Oscillatoria-like protophyte, Anacamptothrix intestinalis Lavier (1938), which was thought to have affinities with the Schizophyta. 
however, there is a close parallel, for the conidia are liberated in the body of the subterranean stages of the insect host, as they are in the fluid and semi-fluid tissues of mackerel, and the radial germination of the conidia in the insect is also very similar. Azygospores are produced by buds from hyphal bodies into which the protoplasm flows (Speare, I92I); a tentative analogy to this may be made by comparing the bud-like outgrowth of protoplasm from the emptied parent hypha (sometimes growing from a hyphal body) which precedes the production of chlamydospores (see Fig. I).

Ichthyosporidium can therefore be regarded, provisionally, as a fungus belonging to the Entomophthorales, having similarities also with other Phycomycetes. The species of this genus are ill-defined and much of the variety of form may be due only to the influences of the different host fishes, both marine and freshwater; but the degree of resistance put up by individual hosts is now known to be a potent influence in controlling the growth-forms of these parasites. It is most likely that some of the forms from European freshwater fishes will prove to be distinct from the more luxuriantly growing I. Hoferi (Plehn \& Mulsow) from trout in Germany, and from various marine fishes round British coasts; and these again may be distinct from the marine forms from the American Atlantic. Provisionally, however, all are here regarded as I. Hoferi; but in view of the poor development of the type species, I. gasterophilum, the present author hesitates to include it in the synonymy.

There is anything but unanimity of opinion on the systematic position of I. Hoferi, but perhaps the recent findings strengthen that of GwynneVaughan \& Barnes (1937, pp. I47-8), that it is included in Entomophthoraceae.

The present findings throw no light on the relationship of Ichthyosporidium and such forms as Chytridiopsis (which Debaisieux, 1916, p. 265, thinks is prematurely placed among Chytrids by Léger \& Duboscq, 1909), and Coelomomyces Keilin (192I), though there is some evidence of flagellospores in both these forms. The mass of felted mycelium in Coelomomyces stegomyiae Keilin, which develops over the viscera of the larval culicid host, and the detachment from it of clavate hyphal tips to form definite sporangia with thick pitted walls, is quite unlike anything in Ichthyosporidium. The early development of the sporangia in Keilin's species (I92I, fig. 5 A-D), showing spheroidal masses with vacuoles and scattered vesicular nuclei, later becoming encapsuled, would, by themselves, have suggested close relationship with the similar bodies in the bodies of fishes described as Ichthyosporidium by Robertson (1908, I909). ${ }^{1}$

1 The spheroidal forms figured by Robertson and others at once recall Rhinosporidium, an internal (and in the early stages intracellular) parasite of mammals. $R$. seeberi (Wernicke, I900), from nasal polyps of man, as figured by Ashworth (1923) is particularly reminiscent; in the fully grown trophic stage it is spheroidal with a vacuolated protoplasm, large numbers of vesicular nuclei and a double wall, the inner thick one being of cellulose. For this and other reasons listed by Ashworth, it was placed near to the Chytridiaceae. The similarity of 
Thus, if too much reliance be placed on the character of the nucleus in such spheroidal masses, occurring alone as parasites, it is easy to be led astray as to their relationships. Jepps (1937, pp. 642-5, fig. 26) identified as Ichthyosporidium a rare parasite of the haemocoele of Calanus finmarchicus; it occurs as a mycelium with clavate tips, having vesicular nuclei scattered through it, and as she points out, it has much in common with the bouillon cultures obtained by Plehn \& Mulsow from Ichthyosporidium Hoferi cysts. She advances the attractive hypothesis that Calanus may thus act as an intermediate host for the fish parasite; but the identification must, for various reasons mentioned above, be viewed with reserve. Yet it is possible that her identification is correct, and that Calanus can act as an occasional reservoir host. But the finding of all apparently essential stages in the mackerel rules out the necessity for an intermediate host in the life cycle. Moreover, its occurrence in Calanus is very rare, for though very large numbers of this and similar copepods have been examined by Dr Jepps, and by Dr Lebour over a period of many years, no further infections have been found (personal communications). While examining the stomach contents of mackerel during their copepod feeding phases, none of them was found infected in this way, in spite of the widespread occurrence of the fungus in the mackerel.

It is possible that the entrance of the fungus into mackerel may be facilitated by the perforation of the gut wall by migrating cestode larvae. The fact that cestode cysts accompanied fungus infections in every case affords no supporting evidence, because the former were present in every mackerel examined; also the two often occurred in contact among the viscera, just under the peritoneum. Chlamydospores have been found adherent to the outer cyst wall of tetrarhynchid cestodes, though no certain record was made of their occurrence inside the cestode cysts.

From his records of Ichthyosporidium Hoferi in herring (Clupea harengus) from the Gulf of Maine, Fish (1934) showed that the maximum infection was found among fish in the shallower, landward waters which they frequent at breeding time; but no such correlation of infection rate and migration could be made for the mackerel. The present data have been analysed in various ways but there is no relationship between infection rate and place of capture, season, age or sex of the fish, though it is possible that extended observations may reveal factors which are significant to the spread of the disease. With this in view, complete records are being deposited in the library of the Marine Biological Association at Plymouth.

It is highly probable that this disease is in a large measure responsible for the widespread unpopularity of mackerel as a food, unless freshly caught. the fully grown encysted hyphal bodies of Ichthyosporidium Hoferi to the cysts of the recently described Rhinosporidium pulmonale Kirschenbiatt (I939), from the lungs of voles in the U.S.S.R., is also striking. Further investigation, however, shows that there is no thallus development in these mammalian parasites beyond the large spherules, the whole of the thallus becoming differentiated into uninuclear spores with chitinous envelopes (as in Amoebidium). 
The high food value of this fish is generally accepted, and its fat content is nearly double that of the herring $\left(25.2\right.$ and $\mathrm{I}_{3} .3 \%$ respectively, according to Chipman \& Langstroth, I930). Sawyer (I929) investigated the growth in culture of Entomophthora spp., and found that the hyphal tips have strong proteolytic enzymes which break down the animal tissues on which they feed; and in insects they penetrate the cuticle (entrance via the intestine was never observed). He proved (pp. I04-7) that while fats and carbohydrates are not essential to the growth of these fungi, proteins are. It is well known, however, that fatty substances accumulate in insects during the growth of these parasites. Even in moderately advanced infections of the mackerel large globules of free fat are found to flow out immediately the kidney is opened, and there is frequently a milky emulsion of fat covering large blood vessels in organs which are infected with non-encapsuled hyphae. The first gross sign of protein decomposition in mackerel, even before its odour becomes offensive, is furnished by the ribs breaking away from the body wall when the venter is slit. Further development of the infection, or post-mortem growth of an originally moderate one, causes the wall of the intestine to be attacked (probably by proteolytic enzymes in solution in the body fluid) and this is soon ruptured, allowing the putrefactive organisms from the lumen to escape and spread, greatly accelerating the general decomposition of the muscles. The presence of a few fish in this state of rapid decay in a barrel will quickly contaminate all the others, not by the direct products of the fungus infection, but secondarily, by their being centres of dissemination of putrefactive bacteria. The remedy is fortunately very simple: splitting and gutting of the fish as soon as possible after they are caught, and subsequently packing them in dry crushed ice (the value of which has recently been emphasized for mackerel marketing in the U.S.A. by Stansby \& Lemon, I94I). In the process of gutting the fish, any badly infected ones would be at once apparent by the brown sauce-like contents of the body cavity, and could be discarded. The rough removal of the alimentary canal, etc. usually involves the tearing away of a considerable portion of the kidney, so that in this simple process the chief sites of infection are removed, and the mackerel, while being slightly more costly, would be a reliable product of comparatively high keeping quality. The offal should, on no account, be tipped into the sea, as it would form centres of infection for other fish, as was shown by Fish (I934).

Most of this work has been carried on during the tenure of the Keddey Fletcher-Warr Studentship, granted by the University of London; the examination of fishes was done mainly at the Marine Biological Laboratory, Plymouth, where samples were kindly put at my disposal. Much gratitude is due to the Director, Dr Stanley Kemp, F.R.S., for his kind co-operation and encouragement, and for arranging for samples of fish to be sent to Cambridge for the later work; to Dr Marie V. Lebour for her kind assistance in the search for infected copepods, and to Dr Margaret W. Jepps for the 
loan of her original material of the infected copepods. The excellent facilities for the mycological study of the parasite in the Botany School of the University of Cambridge were generously given by Prof. F. T. Brooks, F.R.S., and the author is much indebted to him and his staff for the benefits she enjoyed there. For help during the writing of the present account, and for its criticism, the author wishes to thank Dr J. Ramsbottom, O.B.E. (Keeper of Botany, British Museum (Nat. Hist.)).

\section{SUMMARY}

A fungus has been found causing a fatal disease among mackerel in British waters, and a very high rate of infection has been maintained for over three years. It is spread throughout the viscera by the circulation, being particularly common in the kidney and spleen: it is very rare in the muscles and has never been found in the gonads or central nervous system of these fish.

Growth of the aseptate, sparsely branched hyphae is usually radial, from one of three types of central body. The length and thickness of the hyphae varies according to the density of the infected tissue and the degree of resistance which is set up. Connective tissue capsules are laid down round spores and hyphal bodies, occluding the small vessels or capillaries in which they become lodged. Growth of the parasite stretches the capsule, which may become a tubular gallery containing many growth stages. This may effectively seal the parasites which then degenerate; or, more usually, the strong proteolytic enzymes secreted by the advancing hyphae perforate it, and proceed to convert the whole organ into a necrotic mass in which hyphae grow to great lengths. There is always a tendency for hyphal walls to collapse behind the outgrowing hyphae, giving the appearance of hair-like threads with swollen ends.

Any of the following developments may occur, apparently on any hypha, in tissue undergoing necrosis: (I) Bunches of large elongated chlamydospores, with a very hard exospore and a thick (?) gelatinous endospore-a germination pore is present; (2) Single dome-shaped conidia (like those of Entomophthoraceae); (3) Hyphal bodies of various shapes, either growing at once where they become lodged or becoming rounded and encysted-these may subdivide irregularly, each spherule having a separate cyst; (4) Branched conidiophores with rounded tips which contain endo-conidia-liberated as minute amoeboid bodies into the blood vessels; (5) Simple clavate sporangia from the ends of unbranched hyphae, also containing endo-conidia; (6) Hyphal fusions of numerous kinds, immediately proceeding to further outgrowths of similar hyphae; (7) 'Spores produced by hyphal fusion': fusion of two hyphae followed by the participation of neighbouring hyphae which also contribute to form the outer, resistant, rugose wall.

Form (7) is comparatively light and may be the means of dispersal (by faeces or dead fish) in the plankton; infection is thought to take place through the gut wall, especially through the pyloric caeca. The role of the abundantly 
numerous endo-conidia is uncertain. No nuclear division or fusion has been seen in this material. Since growth from the three types of resting body (I), (3) and (7) occurs in the mackerel, no intermediate host is necessary.

Previous descriptions of similar growth forms from freshwater fishes from Europe and from marine fishes from both Europe and America are reviewed; none show the profusion or variety of growth met with in the present investigations on mackerel. Forms (I), (6), (7), and the further development of (4) are described for the first time, as well as some other details of structure.

The affinities with other forms are discussed, and it is decided to regard similar forms from other hosts as provisionally conspecific, and their differences in development as being due to the nature of the hosts-the correct nomenclature being Ichthyosporidium Hoferi (Plehn \& Mulsow, I9II) Pettit, I9I3. The genus is placed in the Entomophthoraceae, but it has similarities with several other Phycomycetes.

The detrimental effect of the disease on mackerel as a commodity is discussed and remedial measures suggested to ensure a higher quality product.

\section{REFERENCES}

AleXeIefF, A., 19I4. Sur le cycle évolutif d'une haplosporidie (Ichthyosporidium gasterophilum Caullery \& Mesnil). Arch. Zool. Expér. et Gén., T. LIV, pp. 30-44, figs. $\mathrm{I}-4$.

Ashworth, J. H., I923. On Rhinosporidium seeberi (Wernicke, I903), with special reference to its sporulation and affinities. Trans. Roy. Soc., Edinburgh, Vol. LIII, pp. $30 \mathrm{I}-42,5$ pls.

AtKINS, D., I929. On a fungus allied to the Saprolegniaceae found in the pea-crab, Pinnotheres. Fourn. Mar. Biol. Assoc., Vol. XVI, pp. 203-I9, figs. I-I3.

Calkins, G. N., I900. Lymphosphoridium truttae nov. gen., nov. sp., the cause of a recent epidemic among brook trout, Salvelinus fontinalis. Zool. Anz., Bd. xxiII, pp. 5I3-20, figs. I-6.

Caullery, M. \& Mesnil, F., I905. Recherches sur les Haplosporidies. Arch. Zool. Expér. et Gén. (4e. sér.), T. IV, pp. IOI-8I, pl. I3.

Chatton, E., I906. Sur la biologie, la spécification et la position systématique des Amoebidium. Arch. Zool. Expér. et Gén. (4e. sér.), Notes et Rev., T. v, pp. 17-32.

Chipman, H. R. \& Langstroth, G. O., 1930. Some measurements of the heatcapacity of fish muscle. Proc. and Trans. Nova Scotian Inst. Sci., Vol. xvII, pp. $175-84$.

Cox, P., I916. Investigations of a disease of the herring (Clupea harengus) in the Gulf of St Lawrence. Contrib. to Canadian Biol. I914-I915, pp. 8I-85, 2 pls.

DANIEL, G. E., I933a. Studies on Ichthyophonus hoferi, a parasitic fungus of the herring (Clupea harengus). I. The parasite as it is found in the herring. Amer. Fourn. Hyg., Vol xvII, pp. 267-76, figs. I-I5.

I933 b. Idem. II. The gross and microscopic lesions produced by the parasite. Amer. Fourn. Hyg., Vol. xvII, pp. 49I-50I.

Debaisieux, P., I9I6. Coelomycidium simulii nov.gen., nov.spec., et remarques sur l'Amoebidium des larves de Simulium. La Cellule, T. xxx, pp. 249-67.

ElLIS, M. F., I930a. Ichthyophonus hoferi Plehn \& Mulsow, a flounder parasite new to North American waters. Proc. and Trans. Nova Scotian Inst. Sci., Vol. xvII, pp. I85-92, figs. I-I2. 
Ellis, M. F., I930b. Protozoan fish parasites of the Saint Andrews region. Proc. and Trans. Nova Scotian Inst. Sci., Vol, xvII, p. 268.

FIsH, F. W., I934. A fungus disease in fishes of the Gulf of Maine. Parasitology, Vol. XxvI, pp. I-I6, figs. I-II, pl. I.

Fischthal, J., I944. Observations on a sporozoan parasite of the eelpout, Zoarces anguillaris, with an evaluation of candling methods for its detection. Fourn. Parasitol., Vol. xxx, pp. 35-6.

Gwynne-Vaughan, H. I. C. \& Barnes, B., I937. The Structure and Development of the Fungi. 2nd ed. Cambridge.

HoFer, B., I893. Eine Salmoidenkränkung. Allgemeine Fischerei-Zeit., N.F., Bd. vIII, p. 168.

1904. Handbuch der Fischkrankheiten. München. 1906. Handbuch der Fischkrankheiten. Stuttgart.

Jepps, M. W., I937. On the protozoan parasites of Calanus finmarchicus in the Clyde Sea Area. Quart. Fourn. Micr. Sci., Vol. Lxxix, pp. 589-658, figs. I-28, pls. 25-28.

Johnstone, J., I906. Internal parasites and diseased conditions of fishes: 3 . Fungi. Trans. Biol. Soc., Liverpool, Vol. xx, pp. 179-85, pl. I6.

- I913. Diseased conditions of fishes: a phycomycetous fungus in a mackerel (Scomber scomber). Trans. Biol. Soc., Liverpool, Vol. xxvII, pp. 28-33, pls. I-2.

- 1920. On certain parasites, diseased and abnormal conditions of fishes. Report for 1919, Lanc. Sea-Fish. Lab., No. xxvIII, pp. 24-33, figs. I-II.

KeIlln, D., I92I. On a new type of fungus, Coelomomyces stegomyiae n.g., n.sp., parasitic in the body cavity of the larvae of Stegomyia scutellaris Walker (Diptera, Nematocera, Culicidae). Parasitology, Vol. xIII, pp. 225-34, figs. I-7.

Kirschendiatt, J. D., I939. A new parasite of the lungs in rodents. Compt. Rend. (Doklady) Acad. Sci. U.R.S.S. T. xxIII, pp. 406-8, figs. I-2.

Laveran, A. \& Pettit, A., i9io. Sur une épizootie des truites. Compt. Rend. Acad. Sci. Paris, T. CLI, pp. $42 \mathrm{I}-3$.

LAvier, G., I938. Sur un protophyte parasite intestinal de poisson marin. Ann. Parasitol., T. xvi, pp. 259-64.

LÉGER, L., I924. Sur un organisme du type Ichthyophone parasite du tube digestif de la Lote d'eau douce. Compt. Rend. Acad. Sci. Paris, T. Clxxix, p. 785.

- 1927. Sur la nature et l'évolution des sphérules décrites chez les Ichthyophonus parasites de la truite. Compt. Rend. Acad. Sci. Paris, T. CLxxx, p. I268.

_ r $929 a$. Obstruction stomachale chez la truite par une formation mycétogène d'origine alimentaire. Ann. Univ. Grenoble (N.S.), Sci. Med., T. vI, pp. 79-85, figs. I-6, pls. I-II.

I $1929 b$. Sur la nature et l'évolution des sphérules décrites chez les Ichthyophonus phycomycètes parasites de la truite. Ann. Univ. Grenoble (N.S.), Sci. Med., T. vI, pp. 133-7, figs. I-IO.

LÉger, L. \& DuboscQ, O., I909. Sur les Chytridiopsis et leur évolution. Arch. Zool. Expér. et Gén. (5e. sér.), Notes et Rev., T. I, pp. 9-13.

LÉGER, L. \& HESSE, E., I923. Sur un champignon du type Ichthyophonus parasite de l'intestin de la truite. Compt. Rend. Acad. Sci. Paris, T. CLxxvI, pp. 420-2.

Neresheimer, E. \& Clodi, C., I9I4. Ichthyophomus hoferi Plehn \& Mulsow, der Erriger des Taumelkrankheit der Salmoniden. Arch. Parasitenk., Bd. xxxIv, pp. $217-48$, figs. I-15, pls. $15-17$.

Ou, S. H., I940. Phycomycetes of China. I. Sinensia, Vol. xI, pp. 33-57, pls. I-5.

Pettit, A., I9I3. Observations sur l'Ichthyosporidium et sur la maladie qu'il provoque chez la truite. Ann. Inst. Pasteur, Paris, T. XxvII, pp. 986-1008, pls. I3-I4.

Plehn, M. \& Mulsow, K., I9II. Der Erriger der 'Taumelkrankheiten' der Salmoniden. Cent. f. Bakt. Parasitenk., Bd. LIX, pp. 63-8, figs. I-6, pl. I. 
Riddell, W. \& Alexander, D. M., I9Ir. Note on a ulcerative disease of the plaice. Proc. and Trans. Liverpool Biol. Soc., Vol. xxvi, p. 155.

RoBERTSON, M., I908. Notes upon a Haplosporidian belonging to the genus Ichthyosporidium. Proc. Roy. Phys. Soc., Edinburgh, Vol. xvII, pp. 175-87, pls. 9-10.

- 1909. Notes on an Ichthyosporidium causing fatal disease in sea trout. Proc. Zool. Soc. London, pp. 399-402, pls. 63-64.

SAvourÉ, P., I905. Recherches expérimentales sur les Mycoses internes et leurs parasites. Arch. de Parasitol., T. x, pp. 5-70, figs. I-I2.

SAWYER, W. H., 1929. Observations on some entomogenous members of the Entomophthoraceae in artificial culture. Amer. Fourn. Bot., Vol. xvI, pp. 87-I2I, pls. 9-I2.

- 1933. The development of Entomophthora sphaerosperma upon Rhopobota vacciniana. Ann. Bot., Vol. xLvII, pp. 799-809, pls. 28-29.

Speare, A. T., I92I. Massospora cicadina Peck, a fungus parasite of the periodical cicada. Mycologia, Vol. xIII, pp. 72-82, pls. 5-6.

- 1922. Natural control of the citrus mealy bug in Florida. U.S. Dept. Agric. Bull., No. III7, pp. I-I8, figs. I-2I.

Stansby, M. E. \& Lemon, J. M., I94I. Studies on the handling of fresh mackerel (Scomber scombrus). U.S. Dept. Interior: Fish and Wild Life Service, Research Repts., No. I, pp. I-46.

Thaxter, R., I888. The Entomophthoraceae of the United States. Mem. Boston Soc. Nat. Hist., Vol. IV, pp. 133-201, pls. I4-2I.

Williamson, H. C., I913. Report on diseases and abnormalities in fishes: Dokus adus an intra-capillary parasite of fish. Rept. Fish. Bd. Scotland (Sci. Investigations) (I9II) II, pp. 4-II, pls. I-8. 